\title{
LXI. On the existence of a new vegeto-alkali in gun- cotton
}

\section{Robert Porrett Esq.}

To cite this article: Robert Porrett Esq. (1847) LXI. On the existence of a new vegeto-alkali in gun-cotton , Philosophical Magazine Series 3, 30:203, 409-412, DOI: 10.1080/14786444708645418

To link to this article: http://dx.doi.org/10.1080/14786444708645418

曲 Published online: 30 Apr 2009.

Submit your article to this journal $\lceil\pi$

山 Article views: 3 
is formed in the subterranean reservoir, to the extent of producing a sudden detonation.

$\mathrm{Be}$ this as it may, as we desired to know whether the natural eruptions of the Strokkur were produced more regularly than those of the Geysir, and had any connexion with them, we only forced the eruptions twice at our arrival, and we noted, in the following table, all the great natural eruptions:-

\begin{tabular}{|c|c|c|}
\hline Dates. & $\begin{array}{c}\text { Forced } \\
\text { Eruptions. } \\
\text { Heights. }\end{array}$ & $\begin{array}{c}\text { Natural } \\
\text { Eruptions. } \\
\text { Hours. }\end{array}$ \\
\hline 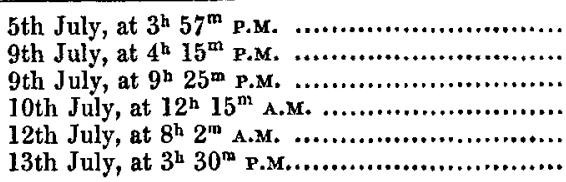 & 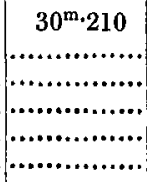 & $\begin{array}{l}\quad 49^{\mathrm{m} \cdot 375} \\
43^{\mathrm{m}} \cdot 528 \\
\text { not measured. } \\
\text { not measured. } \\
\quad 47^{\mathrm{m} \cdot 426}\end{array}$ \\
\hline
\end{tabular}

It will be seen from this table that the natural eruptions of the Strokkur do not present more regularity than those of the Geysir, and that their coincidence with the latter, if it sometimes happens, is not general.

Some observers have admitted that there was a direct communication between the Strokkur and the Geysir: unfortunately I was not able, during ny visit, to collect water from the Strokkur sufficiently freed from the earthy matters coming from the clods of earth which we threw upon it during the first days of our arrival, to bring it back and submit it to an accurate analysis; but the quantity of sulphuretted hydrogen, which I found to be $1^{\text {cc. }} 748$ per litre, differs sufficiently from that which the water of the Geysir contains, to allow us to conceive that these two springs, subjected perhaps to the same cause of subterranean heat, are not, as has been thought, in immediate connexion.

LXI. On the existence of a New Vegeto-Alkali in GunCotton. By Robert Porrett, Esq.*

A $\mathrm{T}$ the last meeting of this Society on the 7 th instant, a joint A communication from Mr. Teschemacher and myself "On the Chemical Composition of Gun-Cotton" was read $\dagger$, and in the last paragraph but one thereof I suggested that a view

* Communicated ly the Chemical Society; having been read Dec. 21, 1846.

$\dagger$ This communication will be found at p. 273 of the present volume of this Journal. 


\section{$410 \mathrm{Mr}$. Porrett on a New Vegeto-Alkali in Gun-Cotton.}

might be taken of the arrangement of its elementary particles which would account for the singular fact of its non-acidity, by supposing it a compound of nitrous acid and oxide of liguin, the said new oxide being also supposed to possess alkaline properties.

It was before mentioned that the action of a small voltaic battery on gun-cotton gave but very slight indications of its decomposition, but that slight as they were they were rather favourable to the suggestion ; the indifference of this compound to the electrical action of the battery I found was owing to its highly non-conducting nature, but I succeeded rather better by moistening the gun-cotton with acetic acid, and placing it in a thin layer between a plate of silver and one of zinc, completing the circuit with a copper wire and leaving them for forty-eight hours so arranged; at the end of that time, on dismounting this little voltaic arrangement, the inner surface of the silver plate was found to be encrusted with a small quantity of matter, which when dry looked white like starch, which powerfully restored the blue colour of reddened litmus paper, and which when heated to redness left a black carbonaceous residue; the minute quantity obtained made further experiments with it impossible, but it increased my desire to be able to procure the same substance by chemical means in any quantity that might be wanted.

After several trials I succeeded by the following process.

I took 2 ounces by measure of nitric acid of the specific gravity $1 \cdot 45$, to which I added 50 grains of gun-cotton; the mixture being gradually heated to $100^{\circ}$ of Fahrenheit's scale and kept below $180^{\circ}$, became quite transparent and fluid, and all the cotton disappeared, being quietly dissolved without any evolution of gas; when a portion of the solution in this state was dropped into water a white precipitate was formed, having all the properties, structure excepted, of the original gun-cotton, the liquid was therefore a simple solution in acid, without decomposition; but on heating the liquid further up to $240^{\circ}$, deep red acid vapours were given off abundantly for a long time, and these collected in a receiver surrounded with ice proved to be hyponitrous acid. The same effect exactly took place when sulphuric acid was used instead of nitric at the same temperature, so that the hyponitrous acid was merely eliminated in both cases, and not formed from the excess of nitric acid used in the former instance; the cold and very concentrated nitric solution containing a great excess of acid was now brought nearly, but not quite, towards a neutral state by pouring into it a strong solution of subcarbonate of potash, after which a solution of bicarbonate of potash was used 
until perfect neutrality was obtained: the liquid in this state became thickened, not only by the quantity of minute crystals of nitrate of potash formed in it beyond what it could hold in solution, but also by an abundant precipitate of a whitish-gray colour, consisting of the new alkali probably in a state of carbonate. The liquid was heated nearly to ebullition, during which its colour became darker, and it was set aside in order that the crystals of nitrate of potash formed on cooling might be separated and the liquid disembarrassed of them as much as possible; after this it was evaporated to dryness by the heat of a water-bath, and the brownish residue was acted upon first by sulphuric æther, which however would not dissolve any portion of it; next by alcohol, specific gravity 0.813 , which took up a very small quantity of the new alkali; then spirit of wine was tried; the solvent power was greater than that of the alcohol, but it had the disadvantage of taking up with the alkaline matter a very minute quantity of the nitrate of potash which accompanied it, so that I could not get an exclusive solvent for the former; the principal quantity by far of the carbonated alkaline oxide of lignin still remained, and I was obliged to use a small quantity of cold, distilled water for its solution, notwithstanding that the water took up at the same time some of the nitrate of potash and bicarbonate of potash remaining in the mass. This aqueous solution contains the new alkali in abundance, but mixed as stated with the other two salts, it acts very powerfully upon reddened litmus paper.

When a portion of the hyponitrous acid is neutralized by an aqueous solution of the new alkali, hyponitrite of oxide of lignin, probably identical with gun-cotton or with xyloidine, is reproduced and precipitated as an insoluble compound.

Thus I have verified the accuracy of my suggestion, excepting that instead of nitrous acid neutralized by a new alkali existing in gun-cotton, it is the hyponitrous acid so neutralized that constitutes that substance. For this new alkali I have proposed the name Lignia, and believe that it opens a wide field for scientific research.

I suspect that in the natural decay of woody fibre from leaves and rotting plants this alkali is produced in combination with acetic acid, and that the acetate of lignia so formed exists in the sap of all vegetables; further, that it is decomposed and deoxidated by light acting on the leaves and bark of trees, reproducing lignin for the assimilation and growth of the plant: its action also on the animal system deserves inquiry. I lay no stress however on these speculations, excepting so far as they may stimulate others to enter into in- 


\section{On some new Researches in Animal Chemistry.}

vestigations which it is impossible for me, consistently with my other duties, to find time for carrying on, and I leave the subject without reserve to those who have more leisure.

I would remark, that the composition of lignia must be that of lignin plus 2 atoms of oxygen given up by the nitric acid in becoming hyponitrous acid; and $I$ would further observe, that the latter acid and lignia forming an insoluble compound, may probably be employed as mutual tests of each other's presence in combinations.

LXII. On some new Researches in Animal Chemistry. Extracted from a Letter from Professor LikBig to Dr. A. W. HoFmanN*.

T AM at present occupied with the investigation of the constituents of the animal fluids which are found without the blood and lymphatic vessels. The fluid from flesh, for example, reacts strongly acid, and the question was, whence arose this acidity? After overcoming more difficulties than I have ever experienced in any investigation, I have for the first time indisputably proved that free lactic and phosphoric acid exist in the whole organism wherever muscle is found. How curious, that in the absence of all proofs on the part of the opponents of lactic acid, I should now demonstrate to them its existence in the flesh of oxen, fowls, calves, and sheep, by preparing and analysing the most beautifully crystallized zinc and lime salts! How wonderful, that in the animal organism acids and alkalies are found separated by a membrane, constituting myriads of little galvanic circles, which, as such, must produce chemical and electrical effects! To the latter class I refer all the observations of Matteucci, which can now be easily explained.

I have further found that the flesh of the muscles of oxen, fowls, sheep, calves, and the carnivorous pike contain creatin, prepared by Chevreul eleven years ago, and which, from Berzelius's not being able to reproduce it, has since then, in a measure, disappeared from the field of science. Creatin is a beautiful substance, having the formula $\mathrm{C}_{8} \mathrm{~N}_{3} \mathrm{H}_{11} \mathrm{O}_{6}$. At the temperature of $100^{\circ} \mathrm{C}$. it loses 2 equivs. of water, and becomes $\mathrm{C}_{8} \mathrm{~N}_{3} \mathrm{H}_{9} \mathrm{O}_{4}=$ glycocoll + ammonia or caffein + amidogen and water. Heated in a stream of hydrochloric acid, creatin loses 4 equivs. of water and takes up 1 of hydrochloric acid. By this treatment, however, its nature is entirely altered, being now converted into a beautiful organic base, the properties of which are totally different from those

* Communicated by the Chemical Society; having been read Dec. 21, 1846. 